\title{
Effect of potash application on the growth and yield of Tomato crop grown in saline condition
}

\author{
Syed Ghias Ali* and Abdur Rab
}

Department of Horticulture, The University of Agriculture, Peshawar - Pakistan

*Corresponding author's email: ghiasghias06@hotmail.com

Citation

Syed Ghias Ali and Abdur Rab. Effect of potash application on the growth and yield of Tomato crop grown in saline condition. Pure and Applied Biology. Vol. 5, Issue 2, 2016, pp287-297.http://dx.doi.org/10.19045/bspab.2016.50037

\begin{tabular}{llll}
\hline Received: 11/01/2016 & Revised: 29/02/2016 & Accepted: 06/03/2016 & Online First: 19/03/2016 \\
\hline
\end{tabular}

\section{Abstract}

The effect of supplemental potash and its sources on the growth and yield of tomato crop grown in salinity stress condition was studied during the year 2012 and 2013 . The tomato plants were irrigated with $0,50,100,150$ and $200 \mathrm{mM} \mathrm{NaCl}$ saline solutions. Supplemental potash was applied from two sources (SOP and MOP) and evaluated against control (no potash supplement). The maximum fresh weight of roots $(8.97 \mathrm{~g})$ and shoot $(217.4 \mathrm{~g})$, dry weight of roots $(3.11 \mathrm{~g})$ and shoot (46.35 g), shoot/root ratio (24.56), number of leaves/plant (110) and yield (7.32 $\left.\mathrm{t}^{-1}\right)$ were recorded in control plants. In contrast, the minimum root and shoot fresh weight (3.63 and $69.71 \mathrm{~g}$ respectively), root and shoot dry weight ( 0.76 and $11.55 \mathrm{~g}$ respectively), shoot/root ratio (18.46), number of leaves/plant (52) and yield $1.15 \mathrm{t}^{-1}$, were recorded for the treatment with $200 \mathrm{~m} M \mathrm{NaCl}$. Application of supplemental potash and its sources significantly affected the salinity induced changes in tomato plants. The SOP source of potassium resulted in the highest fresh root and shoot weights $(6.74 \mathrm{~g}, 158.5 \mathrm{~g}$ respectively), dry weight of root $(2.17 \mathrm{~g})$ and shoot $(32.11 \mathrm{~g})$, shoot root/ratio (23.23), number of leaves per plant (88.4) and yield 4.60 t.ha $^{-1}$. The interaction of salinity and supplemental potash also significantly affected the number of leaves per plant and yield. The highest number of leaves per plant (109) and yield (7.56 t.ha $\left.{ }^{-1}\right)$ in control plants, declined with increasing salinity to the minimum of 41 and 0.42 t.ha $^{-1}$ with $200 \mathrm{mM} \mathrm{NaCl}$ + no supplemental potash. Both the potash sources at all levels of salinity had relatively higher number of leaves per plant and yield as compared no supplemental potash treatment. However, at each level of salinity, SOP as potash source resulted in higher number of leaves and yield as compared to MOP.

Key words: Salinity; Tomato; Growth; Yield; MOP; SOP

\section{Introduction}

Salinity is a major abiotic stress that affects approximately $7 \%$ of the world's total land area. More than 800 million hectares of land around the world are affected by salinity [1], which results in billions of dollars in crop production losses. To improve crop growth and production in the salt-affected soils, the excess salts must be removed from the root zone. Methods commonly used in reclamation such soils are scraping, flushing and leaching [2]. These methods were found to be very expensive. 
Another approach to minimize the harmful effect of salinity is the use of foliar feeding of nutrients for increasing plant salinity tolerance by alleviating $\mathrm{Na}^{+}$and $\mathrm{Cl}^{-}$injury to plants [3]. Application of certain nutrient such as $\mathrm{Fe}, \mathrm{Zn}$ and $\mathrm{Mn}$ to tomato seedlings increase the dry weight of different plant organs [4] indicating that salinity stress induces nutrients deficiency that can be corrected with supplemental nutrients application. Salinity stress involves accumulation of $\mathrm{Na}$ in root zone that inhibit $\mathrm{K}$ uptake, thus, inducing $\mathrm{K}$ deficiency and decrease yield [5]. Potassium is an essential and major plant nutrient, which lowers the osmotic potential in the stele of roots, required for turgor pressure driven solute transport in the xylem and plant water balance [6]. Potassium also plays an important role in enzyme activation, protein synthesis, photosynthesis, osmoregulation, stomatal movement, energy transfer, phloem transport, cation-anion balance and stress resistance [7]. Thus, an optimum potassium level in the cytoplasm is essential for the maintenance and survival of plants under saline condition [8]. At its optimal concentration in the plants, $\mathrm{K}^{+}$ions may enhance the rate of photosynthesis [9] and, thus, decrease the adverse effect of salt stress. Salt tolerance is partially correlated with the ability to avoid the accumulation of $\mathrm{Na}^{+}$and/or to maintain adequate levels of $\mathrm{K}^{+}$ in the shoots $[\mathbf{1 0}, \mathbf{1 1}]$. By contrast potassium deficiency may disrupt metabolism [12], resulting in stunted growth and decreased yield [5]. The tomatoes require optimum $\mathrm{K}^{+}$ for good growth and yield [13]. While the soil $\mathrm{K}$ may be adequate, the plants require additional $\mathrm{K}^{+}$under saline stress [13]. The optimum levels of Potassium also promote the uptake of other nutrients [14] and may have a synergistic effect with other nutrients [13]. In Pakistan, both sulphate of potash (SOP) and muriate of potash (MOP) are commonly used as potash source and both have been found beneficial [15]. SOP contains $50 \% \mathrm{~K}_{2} \mathrm{O}$ and $18 \%$ sulphur while MOP contains $62 \% \mathrm{~K}_{2} \mathrm{O}$ and $45 \%$ chloride [16]. However, MOP has a very elevated salt index (salt index $=116$ ) in comparison with that for SOP (salt index = 46) [17]. However, MOP is considered a relatively cheaper source of potassium. Keeping in view the salinity induced $\mathrm{K}^{+}$deficiency and its adverse effects on the plant; the current research was initiated to investigate the influence of potassium application from different sources on minimizing the adverse effects of salinity in tomato.

\section{Materials and methods}

The experiment was conducted during the year 2012 and 2013 at the Centre of Plant Biodiversity and Botanical Garden, University of Peshawar, Azakhel, Nowshera, KP. In this experiment the overall affect of supplemental potassium (SOP and MOP) in saline condition was studied on vegetative growth of shoot and root (fresh weight, dry weight, shoot root ratio, number of leaves) and yield. The experiment was conducted according to two factorial randomize complete block design (RCBD) having five salinity levels and two potassium sources. There were three replications of each treatment and 3 plants in each replication.

\section{Experimental procedure}

The effect of supplemental potassium on tomato growth and physiological changes was investigated by exposing tomato plants to $0,50,100,150$ and $200 \mathrm{mM} \mathrm{NaCl}$ and application of $220 \mathrm{~kg} / \mathrm{ha}$ supplemental potash from two sources i.e. Murate of Potash (MOP), Sulfate of Potash (SOP) and control (no Potash) along with a basal dose of $\mathrm{N} 120$ and $\mathrm{P}_{2} \mathrm{O}_{5} 80 \mathrm{~kg} / \mathrm{ha}$ as urea and triple super phosphate, respectively. The potassium dose of $220 \mathrm{~kg} / \mathrm{ha}$ was applied from both sources in two split doses; All P and half of $\mathrm{N}$ and $\mathrm{K}$ fertilizers were manipulated in the media at the time of seed 
sowing and the remaining $\mathrm{N}$ and $\mathrm{K}$ fertilizers were applied at flower initiation stage as side dressing. The same methods and materials were followed as for first experiment. The plants were harvested at the end of the growing season and the data were recorded on the following parameters.

Fresh and dry weight measurements of root and shoots

Fresh root and shoot weights were determined after harvesting the fruits. The plants were carefully uprooted from the planting tube and divided into root and shoot tissue by cutting at the ground levels, using an electric balance and measuring weight in gram to the third decimal.

Root and shoot tissues were oven dried at 80 ${ }^{0} \mathrm{C}$ for 48 hours for dry weight measurements.

\section{Shoot-root ratio}

Shoot and root ratio was calculated by using the following formula:

Shoot / Root Ratio $=\frac{\text { Shoot F.Wt }}{\text { Root F.Wt }}$

\section{Number of leaves per plant}

The number of leaves per plant was determined by counting the number of leaves at the time of harvest. Data was recorded on three plants in each treatment and replication and averaged to represent corresponding treatments and replications.

\section{Yield (Tonnes per hectare)}

All the marketable tomato fruit were weighted after picking and the total yield per plant was recorded in kilograms. Yield (tonnes per hectare) was then estimated from nine plants for each treatment.

\section{Statistical analysis:}

Statistical analysis was performed as for two factorial randomized complete block design (RCBD) [18]. The means were separated by the least significant difference (LSD) using MSTATC (Michigan State University, East Lansing, MI).

\section{Results and discussion Fresh weight}

The root fresh weight was significantly affected by salinity and potassium application. However, the interaction of salinity levels and potassium treatment was not significant. The root fresh weight decreased with increasing salinity levels from $8.97 \mathrm{~g}$ in control plants to $6.74,5.28$ and 4.38 in plants exposed to 50, 100 and $150 \mathrm{~m} M \mathrm{NaCl}$ levels respectively. The minimum root fresh weight $(3.63 \mathrm{~g})$ was recorded with $200 \mathrm{~m} M \mathrm{NaCl}$ stress. The difference in 150 and $200 \mathrm{mM} \mathrm{NaCl}$ stress was, however, not significant.

Potash application also significantly affected the root fresh weight in relation. The root fresh weight in control plants (4.93 g) increased significantly to $5.73 \mathrm{~g}$ and $6.74 \mathrm{~g}$ when supplemental potash was applied from MOP and SOP sources respectively (Table $1)$.

The shoot fresh weight was also significantly affected by salinity levels and potash sources. The fresh weight of non stressed tomato plants $(0 \mathrm{mM} \mathrm{NaCl})$ was the maximum $(217.4 \mathrm{~g})$, which declined with increasing salinity levels to the minimum of $69.71 \mathrm{~g}$ in plant exposed to $200 \mathrm{mM} \mathrm{NaCl}$ stress. Among the potash treatments, the mean shoot fresh weight was $113.1 \mathrm{~g}$ in control treatment (no supplemental potash application), that increased to 124.8 and $158.5 \mathrm{~g}$ with supplemental potash application as MOP and SOP respectively. The interaction between salinity and potash sources was not significant.

The fresh weight of the plant roots and shoots is a common index of plant response to abiotic stresses, including salinity [19]. Salinity decreased both the root and shoot fresh weight by 58.1 and $67.93 \%$ respectively. It is believed that salinity stress is in part mediated through $\mathrm{K}$ deficiency and subsequent inhibition of plant growth [20]. 
While, the roots are plant organs directly exposed to salinity, the shoot system is affected more adversely by high salt concentration [21, 22]. Thus, the decline in fresh weight was more in the shoot than the root system. The decrease in fresh weight may be attributed to increased osmotic pressure around the roots, which decreases water uptake by root in plants grown in saline conditions [23, 24]. The decreased water uptake in plants exposed to salinity stress may be an adoptive strategy to avoid excessive $\mathrm{Na}^{+}$uptake by the plant [25] Salinity may also inhibit cell expansion in the root and shoot system by decreasing cytokines production [26]. Furthermore, decreased leaf area and stomatal closure, that reduces transpiration and hence the uptake of water by the plant [27]. The greater reduction in shoot fresh weight can also be attributed a decline in net photosynthesis and limited supply of carbohydrate in the growing cells, which inhibits the growth in shoot system in plants exposed to salinity stress [28].

Potassium application decreased the salinity induced decrease in fresh weight of both the root and shoot tissue. While, salinity stress may cause stomatal closure by inducing $\mathrm{K}^{+}$ deficiency [27], application of $\mathrm{K}^{+}$increases the turgor pressure of guard cells and keep the stomata open [7]. Thus, while salinity stress inhibit photosynthesis by closing stomata [9, 29], K application may improve the water uptake [30] by acting as an osmoticam [7]. The increased fresh weight clearly demonstrates that potassium application enhances the movement of water, nutrients and carbohydrates in plant tissue [31]. Therefore, supplemental potash inhibits the decline in fresh weight due to salinity [32, 33].

While both MOP and SOP enhanced the root and shoot fresh weight, SOP was superior in decreasing the salinity induced decline in the root and shoot fresh weight.
The root fresh weight in MOP and SOP treated plant was 16.26 and $36.6 \%$ higher than control. By contrast, the shoot fresh weight in SOP treated plant was $40.14 \%$ higher than control. The superiority of SOP in maintaining high fresh weight of both the root and shoot system could be due to the presence of $\mathrm{K}$ and $\mathrm{S}$, the building blocks of this fertilizer [34] and its lower salt index per unit of $\mathrm{K}_{2} \mathrm{O}$ as compared to MOP [17].

\section{Dry weight}

Salinity treatments decreased the root dry weight significantly. The maximum root dry weight $(3.11 \mathrm{~g})$ was recorded in control (0 $\mathrm{m} M \mathrm{NaCl})$ plants, which declined significantly to $2.16,1.49,1.10$ and $0.76 \mathrm{~g}$ with increasing salinity stress levels to 50 , 100,150 and $200 \mathrm{~m} M \mathrm{NaCl}$ respectively. Likewise, the dry weight of roots varied significantly with supplemental potassium application. The control plants had the least root dry weight $(1.32 \mathrm{~g})$ that increased significantly to $1.68 \mathrm{~g}$ and $2.17 \mathrm{~g}$ with supplemental potash application as MOP and SOP respectively. The interaction of salinity treatments and potassium application was not significant (Table 1).

The shoot dry weight was significantly affected by salinity stress and supplemental potash sources. The means across salinity levels indicated the highest shoot dry weight $(46.35 \mathrm{~g})$ with $0 \mathrm{~m} M \mathrm{NaCl}$ treatment, which declined to $33.13,22.70$ and $16.64 \mathrm{~g}$ with increasing salinity stress levels to 50, 100 and $150 \mathrm{mM} \mathrm{NaCl}$ accordingly. The least $(11.55 \mathrm{~g})$ shoot dry weight was recorded when tomato plants were exposed to 200 $\mathrm{m} M \quad \mathrm{NaCl}$ stress. Application of supplemental potash resulted in significantly higher shoot dry weight with SOP source $(32.11 \mathrm{~g})$ than MOP (24.49 g) and Control (21.56 g). The difference between MOP and control was, however, not significant (Table $1)$.

The root and shoot dry weight decreased by 75.6 and $75.08 \%$ and with increasing 
salinity from 0 to $200 \mathrm{~m} M \mathrm{NaCl}$. Salinity stress decreases the plant dry weight in a number of crops including tomato [35-37]. Salinity stress increases $\mathrm{Na}^{+}$concentration around the roots, that out compete $\mathrm{K}^{+}$ uptakes [38]. Thus, increasing $\mathrm{Na}^{+}$uptake induce $\mathrm{K}^{+}$deficiency in the plant tissue [39] and decrease the root and shoot dry weight $[4,33,39]$ and plant growth [40].

Supplemental potash application decreased the adverse effects of salinity on dry weight accumulation. Since, Potassium is required for photosynthesis [9] and regulating several enzymes needed in abiotic stress condition [41] as well as translocation of photo assimilates [42]. Therefore, the increased root and shoot dry weight with potassium application may be attributed to improved $\mathrm{K}$ concentration in the tissue [43].

Among the potassium sources, the increase in root dry weight was 27.7 and $65.0 \%$ higher than control in MOP and SOP treated plants. Similarly, the shoot dry weight also increased by $48.9 \%$ with SOP treatment while, the MOP was at par with control, indicating that SOP is a superior source to enhance root and shoot dry weight in plants grown under saline condition. It is suggested that in saline conditions, MOP further increased the chloride content of the soil [44]. Therefore, high concentrations of $\mathrm{Cl}^{-}$in the soil solution may depress nutrient-ion activities and produce extreme ratios of $\mathrm{Cl}^{-}$ $/ \mathrm{NO}_{3}{ }^{-}$and decreased nitrate uptake [45].

\section{Shoot-root ratio}

The shoot root ratio significantly decreased with the increasing levels of salinity as well as with application of potash in the same treatments of salinity (Table 1). Significantly higher shoot root ratio (24.56) was recorded with $0 \mathrm{~m} M \mathrm{NaCl}$ treatment that decreased to 18.46 with increasing stress level to $200 \mathrm{~m} M \mathrm{NaCl}$. The application of supplemental potash had source dependent effect, where SOP treatment resulted in significantly higher (23.23) shoot/ root ratio than MOP (20.57) and control (21.58). The interaction of salinity treatments and potassium application was not significant. The shoot/root ratio is a function of fresh weight gain in shoot and roots. Hence, it indicates the sensitivity of different plant parts to an abiotic stress. The shoot/root ratio decreased significantly with increasing salinity stress. The shoot/root ratio in control plants was $24.84 \%$ higher than the maximum salinity stress $(200 \mathrm{mM} \mathrm{NaCl})$. The plant biomass and yield are the most widely used indices to evaluate the response of plants to abiotic stress including salinity $[\mathbf{1 9}, \mathbf{2 0}]$. When roots are exposed to the salt stress conditions, the root biomass is negatively affected [46]. The decreased root biomass in saline conditions can be attributed to inhibition of cell growth and roots killing [47], due to salinity induced water deficit [48]. However, the decline in shoot and root fresh weight in the present study shows that, roots are less sensitive than the shoot system [49]. Thus, the shoot/root fresh weight ratio decreased with increasing salinity [50]. Since, the root directly experience the salt stress, the relatively less sensitivity of root system than shoot system appears an adoptive strategy, to recover from stress effects if the condition are improved [51]. It appears as a strategy that potassium application from MOP and SOP sources had the opposite effect on shoot/root. While, SOP increased the shoot/root by $7.64 \%$ compared to control, MOP declined it by $4.68 \%$ (Table 1 ). 
Table 1. Effects of potassium (MOP and SOP) on saline stressed tomato shoot fresh weight, shoot dry weight, root fresh weight, root dry weight and shoot root ratio

\begin{tabular}{|c|c|c|c|c|c|}
\hline \multirow[t]{2}{*}{ Salinity levels } & \multicolumn{2}{|c|}{ Fresh weight (g) } & \multicolumn{2}{|c|}{ Dry weight (g) } & \multirow{2}{*}{$\begin{array}{c}\text { Shoot Root } \\
\text { Ratio }\end{array}$} \\
\hline & Root & Shoot & Root & Shoot & \\
\hline $0 \mathrm{~m} M$ & $8.968 \mathrm{a}$ & $217.4 \mathrm{a}$ & $3.110 \mathrm{a}$ & $46.35 \mathrm{a}$ & $24.56 \mathrm{a}$ \\
\hline $50 \mathrm{~m} M$ & $6.739 b$ & $163.6 \mathrm{~b}$ & $2.164 \mathrm{~b}$ & $33.13 \mathrm{~b}$ & $23.80 \mathrm{ab}$ \\
\hline $100 \mathrm{~m} M$ & $5.281 \mathrm{c}$ & $117.9 \mathrm{c}$ & $1.486 \mathrm{c}$ & $22.70 \mathrm{c}$ & $22.38 \mathrm{~b}$ \\
\hline $150 \mathrm{~m} M$ & $4.384 \mathrm{~cd}$ & $91.98 \mathrm{~cd}$ & $1.095 \mathrm{~cd}$ & $16.54 \mathrm{~cd}$ & $20.23 c$ \\
\hline $200 \mathrm{~m} M$ & $3.632 \mathrm{~d}$ & $69.71 \mathrm{~d}$ & $0.757 \mathrm{~d}$ & $11.55 \mathrm{~d}$ & $18.46 \mathrm{~d}$ \\
\hline LSD at $\alpha 0.05$ & 1.012 & 30.76 & 0.456 & 7.348 & 1.576 \\
\hline Percent Change & $-58.1 \%$ & $-67.93 \%$ & $-75.6 \%$ & $-75.08 \%$ & $-24.84 \%$ \\
\hline \multicolumn{6}{|l|}{ Potassium source } \\
\hline Control & $4.932 \mathrm{c}$ & $113.1 \mathrm{~b}$ & $1.316 \mathrm{c}$ & $21.56 \mathrm{~b}$ & $21.58 \mathrm{~b}$ \\
\hline MOP & $5.734 \mathrm{~b}$ & $124.8 \mathrm{~b}$ & $1.681 \mathrm{~b}$ & $24.49 b$ & $20.57 \mathrm{c}$ \\
\hline SOP & $6.737 \mathrm{a}$ & $158.5 \mathrm{a}$ & $2.171 \mathrm{a}$ & $32.11 \mathrm{a}$ & $23.23 \mathrm{a}$ \\
\hline LSD at $\alpha 0.05$ & 0.7838 & 23.82 & 0.3532 & 5.692 & 1.221 \\
\hline Percent Change & $+36.6 \%$ & $+40.14 \%$ & $+65 \%$ & $+48.93 \%$ & $+7.64 \%$ \\
\hline
\end{tabular}

Means followed by similar letters in a column are non-significantly different from each other at $\alpha$ 0.05 . (+) and (-) signs in percent changes correspond to increase and decrease respectively

\section{Number of leaves/ plant}

The mean number of leaves per plant decreased significantly with the increasing levels of salinity as well as with application of supplemental potash. The highest number of leaves per plant (110) was recorded in plant grown at $0 \mathrm{~m} M \mathrm{NaCl}$ stress, which decreased with increasing salinity to a minimum of 52 in plants exposed to 200 $\mathrm{m} M \mathrm{NaCl}$ stress. The application of supplemental potash had source dependent effect on the number of leaves per plant. The SOP treatment resulted in the highest number of leaves per plant (88) compared to 84 and 77 leaves/ plant with MOP and control treatments respectively. The interaction of salinity treatments and supplemental potash application significantly affected the number of leaves per plant. Increasing salinity decreased the number of leaves from the maximum of 109 in control plants to the minimum (41) in plants exposed to $200 \mathrm{mM} \mathrm{NaCl}+$ no supplemental potash treatment. Whereas, application of supplemental potash resulted in higher number of leaves at each level of salinity as compared to control, the SOP source was more effective than MOP in retaining higher number of leaves per plant (Table 2). The plant biomass and yield are the most widely used indices to evaluate the response of plants to abiotic stress including salinity $[19,20]$. Salinity stress decreases the number of branches in tomato [52-54] by decreasing cytokinin synthesis [55]. The decreased cytokinin decreases the leaf area $[19,56]$ and chlorophyll content of plants exposed to salinity stress $[57,58]$ and enhances leaf senescence [59].

Yield (t. ha-1)

The mean yield was the maximum $(7.32 \mathrm{t}$. $\left.\mathrm{ha}^{-1}\right)$ in non-stressed plants $(0 \mathrm{mM} \mathrm{NaCl}$ treatment), followed by 4.25 and $2.92 \mathrm{t}^{\mathrm{h} \mathrm{ha}^{-1}}$ by plants exposed 50 and $100 \mathrm{~m} M \mathrm{NaCl}$ treatments respectively (Table-2). The yield decreased to 2.22 and $1.15 \mathrm{t}$. ha $^{-1}$ with increase in salinity stress levels to 150 and $200 \mathrm{~m} M \mathrm{NaCl}$ respectively. Supplemental 
potash increased the yield of tomato in saline condition significantly. The highest yield (4.60 t. ha ${ }^{-1}$ ) was recorded with SOP application followed by MOP treatment (4.20 t. ha $\left.{ }^{-1}\right)$; whereas the least yield (3.72 t. $\mathrm{ha}^{-1}$ ) was in control condition (no supplemental potash). The yield of tomato plants under salinity stress decreased significantly with increasing salinity but the decline was less with supplemental potash application. Salinity decreases the uptake of water by the plant and fruit, thus decreases the rate of fruit expansion [60]. The rate of photosynthetic [61-63] as well the transport of photosynthetic products from leaves also decline in plants grown in saline condition [64]. Thus, both osmotic stress and low photosynthates availability, in plants exposed to salinity stress, may cause small size fruit, that decreases the yield $[20,35$, 65]. Since salinity effects are partly mediated through a decrease potassium uptake [12], its deficiency may also contribute to decreased yield [66]. Thus, enhancing $\mathrm{K}$ availability through supplemental potassium application may enhance photosynthesis and photoassimilates translocation [67] that resulted in higher yield [68]. Besides, increasing $\mathrm{K}$ in tissue, potassium treatment may also increase the phosphorus content of tomato [14], indicating a positive effect on other nutrients in the plant and, thus, contribute to less yield losses due to salinity [13]. Potassium treatment with MOP and SOP sources resulted in 12.90 and $23.66 \%$ increase respectively in the yield over control. The superiority of SOP over MOP in increasing tomato yield is in conformity with [69] but contrary to the findings of [70], who reported that MOP treated tomato plants gave higher yield than that of SOP under field conditions. The differences in response of tomato to $\mathrm{K}$ sources could be due to cultivars of tomato understudy or the soil and climatic condition, especially salinity stress in this study [14].

Table 2. Effects of supplemental potash (MOP and SOP) on number of leaves per plant and yield of tomato exposed to different levels of salinity

\begin{tabular}{c|cccc|cccc}
\hline \multirow{2}{*}{$\begin{array}{c}\text { Salinity } \\
\text { Levels }\end{array}$} & \multicolumn{3}{|c|}{ No. of Leaves/Plant } & \multicolumn{4}{c}{ Yield t.ha $^{\mathbf{1}}$} \\
\cline { 2 - 9 } & Control & MOP & SOP & Means & Control & MOP & SOP & Means \\
\hline $0 \mathrm{~m} M$ & 109 & 113 & 107 & $110_{\mathrm{a}}$ & 7.56 & 7.12 & 7.27 & $7.32_{\mathrm{a}}$ \\
$50 \mathrm{~m} M$ & 101 & 105 & 106 & $104_{\mathrm{b}}$ & 5.57 & 6.45 & 6.73 & $6.25_{\mathrm{b}}$ \\
$100 \mathrm{~m} M$ & 76 & 84 & 95 & $85_{\mathrm{c}}$ & 3.26 & 4.26 & 4.45 & $3.99_{\mathrm{c}}$ \\
$150 \mathrm{~m} M$ & 57 & 65 & 71 & $64_{\mathrm{d}}$ & 1.79 & 2.26 & 2.42 & $2.16_{\mathrm{d}}$ \\
$200 \mathrm{~m} M$ & 41 & 51 & 63 & $52_{\mathrm{e}}$ & $0.42^{2}$ & 0.89 & 2.15 & $1.15_{\mathrm{e}}$ \\
Means & $76.8_{\mathrm{c}}$ & $83.6_{\mathrm{b}}$ & $88.4 \mathrm{a}$ & & $3.72_{\mathrm{c}}$ & $4.196 \mathrm{~b}$ & $4.604 \mathrm{a}$ & \\
\hline
\end{tabular}

Interaction LSD for Leaves at $\alpha 0.05=13.579$

Interaction LSD for Yield at $\alpha 0.05=0.782$

Means followed by similar letters in a column are non-significantly different from each other at $\alpha 0.05$

\section{Conclusion}

It is concluded from this study that salinity decreased the growth such as root and shoots fresh weight; root and shoot dry weight, number of leaves per plant, shoot/root ratio and yield of tomato. The salinity induced decline in growth and yield could be decreased by the application of supplemental potassium to tomato plants grown under saline condition. Among the potash sources, SOP was more effective than MOP in increasing root and shoots 
fresh and dry weight, number of leaves per plant, shoot/root ratio and yield.

\section{Author's Contributions}

Carried out the research work: SG Ali, Collects and analyse the data: A Rab, Writing the first draft: A Rab, Provided the basic concept and design of the study: A Rab, Interpreted the data and revising the draft: A Rab.

\section{Acknowledgement}

I am thankful to the Director, Centre of Plant Biodiversity and Botanical Garden, University of Peshawar for providing field and labor for conducting the experiment in the Botanical Garden.

\section{References}

1. Shabala S \& Cuin TA (2008). Potassium transport and plant salt tolerance. Physiol Plantarum 133(4): 651-669.

2. Siyal AA, Siyal AG \& Abro ZA (2002). Salt affected soils their identification and reclamation. Pak J Appl Sci 2(5): 537540.

3. Jouyban Z (2012). The effects of salt stress on plant growth. Tech J Eng App Sci 2(1): 7-10.

4. El-Fouly MM, Moubarak ZM \& Salama ZA (2002). Micronutrient foliar application increases salt tolerance of tomato seedlings. Proc. Inter. Symp. On "Techniques to Control Salination for Horticultural Productivity" Eds. U. Akosy et al., Acta Horti 573: 377-385.

5. Thalooth AT, Tawfik MM \& Mogda HM (2006). A comparative study on the effect of foliar application of zinc, potassium and magnesium on growth under water stress conditions. World J Agri Sci 2: 3746.

6. Zayton A, El-Shafei A, Allam K \& Mourad M (2009). Effect of water salinity and potassium fertilizer levels on tomato productivity and water consumption in Siwa Oasis. Misr J Agri Eng 26(1): 107131.

7. Marschner P (2012). Marschner's Mineral Nutrition of Higher Plants, $3^{\text {rd }}$ (ed). Academic Press. London. Pp. 178-189.
8. Kant S \& Kafkafi U (2002). Potassium and abiotic stresses in plants. In: Pasricha NS, Bansal SK (eds), Potassium for sustainable crop production. Gurgaon, India. pp. 233-251.

9. Jin SH, Huang JQ, Li XQ, Zheng BS, Wu JS, Wang ZJ, Liu GH \& Chen M (2011). Effects of potassium supply on limitations of photosynthesis by mesophyll diffusion conductance in Carya cathayensis. Tree Physio 10: 1142-1151.

10. Blumwald E, Aharon GS \& Apse MP (2000). Sodium transport in plant cells. Biochim Biophys Acta 1465: 140-151.

11. Lacerda CF, Cambraia J, Oliva MA \& Ruiz HA (2001). Plant growth and solute accumulation and distribution in two sorghum genotypes, under $\mathrm{NaCl}$ stress. Rev Bras Fisiol Veg 13: 270-284.

12. Wang $M$, Zheng Q, Shen Q \& Guo S (2013). The critical role of potassium in plant stress response. Int J Mol Sci 14: 7370-7390.

13. Khan MZ, Muhammad S, Naeem MA, Akhtar ME \& Khalid M (2006). Response of some wheat (Triticum aestivum L.) varieties to foliar application of $\mathrm{N}$ and $\mathrm{K}$ under rainfed conditions. Pak J Bot 38(4): 1027-1034.

14. Akhtar ME, Khan MZ, Rashis MT, Ahsan Z, Ahmad S (2010). Effect of potash application on yield and quality of tomato (Lycopersicon esculentum Mill.). Pak J Bot 42: 1695-1702.

15. Akhtar ME, Saleem MT \& Stauffer MD (1998). Research and development on the use of muriate of potash (MOP) in Pakistan, a resume of accomplishments, 1993-98, PARC, Islamabad, Pakistan.

16. Santos BM (2012). Comparison of preplant potassium sources and rates for tomato production in Florida. Pro: Florida State Horti Soc 125: 155-157.

17. Maynard DN \& Hochmuth GJ (2007). Knott's handbook for vegetable growers. John Wiley \& Sons. Hoboken, NJ. Pp. 167-168.

18. Steel RGD \& Torrie JH (1997): Principles and procedures of statistics: A 
biometrical approach: $3^{\text {rd }}$ (ed). McGrawHill, New York.

19. Babu MA, Singh D \& Gothandam KM (2012). The effect of salinity on growth, hormones and mineral elements in leaf and fruit of tomato cultivar PKM1. $J$ Anim Plant Sci 22(1): 159-164.

20. Juan M, Rosa M, Rivero MR, Romero L \& Ruiz JM (2005). Evaluation of some nutritional and biochemical indicators in selecting salt-resistant tomato cultivars. Envir Exp Bot 54: 193-201.

21. Dash M \& Panda SK (2001). Salt stress induced changes in growth and enzyme activities in germinating Phaseolus mungo seeds. Biologia Plantarum 44(4):587-589.

22. Delgado IC \& Sanchez-Raya AJ (2007). Effects of sodium chloride and mineral nutrients on initial stages of development of sunflower life. Commun Soil Sci Plant Analysis 38: 2013-2027.

23. Guo SW, Shen QR \& Brueck H (2007). Effects of local nitrogen supply on water uptake of bean plants in a split root system. J Integra Plant Bio 49: 472-480.

24. Al-Karaki GN (2001). Germination, sodium and potassium concentration of barley seeds as influenced by salinity. $J$ Plant Nutri 24: 511-522.

25. Yeo AR (1998). Molecular biology of salt tolerance in the context of whole-plant physiology. J Exp Bot 49(323): 915-929.

26. Rewald B, Shelef O, Ephrath JE \& Rachmilevitch S (2013). Adaptive plasticity of salt-stressed root systems. Chapter 6. In: P. Ahmad MM, Azooz \& Prasad MNV (eds), Ecophysiology and responses of plants under salt stress. Springer, New York. pp. 169-202

27. Romero-Aranda R, Soria $\mathrm{T} \&$ Cuartero J (2001). Tomato plant-water uptake and plant-water relationships under saline growth conditions. Plant Sci 160: 265272

28. Munns R, Schachtman DP \& Condon AG (1995). The significance of a two-phase growth response to salinity in wheat and barley. Aust J Plant Physiol 22: 561-569.

29. Tomemori H, Hamamura K \& Tanabe K (2002). Interactive effects of sodium and potassium on the growth and photosynthesis of spinach and komatsuna. Plant Prod Sci 5: 281-285.

30. Kaya C, Kirnak H \& Higgs D (2001). Enhancement of growth and normal growth parameters by foliar application of potassium and phosphorus in tomato cultivars grown at high $(\mathrm{NaCl})$ salinity. J Plant Nutr 24(2): 357-367.

31. George R \& Schmitt M (2002). Potassium for crop production. Minnesota Extension 800, 863-876.

32. Noaman MN (2004). Effect of potassium and nitrogen fertilizers on the growth and biomass of some halophytes grown under high levels of salinity. J Agron 3: 25-30.

33. Safaa R, El L, Magdi T, Abde H \& Fatma R (2013). Effect of Potassium Application on Wheat (Triticum aestivum L.) Cultivars grown under salinity stress. World Appl Sci J 26(7): 840-850.

34. Bhatti AU (2011). Potash need assessment and use experience in Khyber Pakhtunkhwa (KP). Soil Envir 30(1): 2735.

35. Yurtseven E, Kesmez GD \& Unlukara A (2005). The effects of water salinity and potassium levels on yield, fruit quality and water consumption of a native central Anatolian tomato species (Lycopersicon esculentum). Agri Water Manage 78: 128-135.

36. Hajer AS, Malibari AA, Al Zahrani H.S \& Almaghrabi OA (2006). Responses of three tomato cultivars to sea water salinity. Effect of salinity on the seedling growth. African J Biotech 5: 855-861.

37. Amini F\& Ehsanpour AA (2006). Response of tomato cultivars to MS, water agar and salt stress in vitro culture. Pak J Biologi Sci 9(1): 170-175.

38. Sarwar G \& Ashraf MY (2003). Genetic variability of some primitive bread wheat 
varieties to salt tolerance. Pak J Bot 35: 771-777.

39. Khan A, Shaheen Z \& Nawaz M (2013). Amelioration of salt stress in wheat (Triticum aestivum L.) by foliar application of nitrogen and potassium. Sci Tech Develop 32: 85-98

40. Degl'Innocenti E, Hafsi C, Guidi L \& Navari-Izzo F (2009). The effect of salinity on photosynthetic activity in potassium-deficient barley species. $J$ Plant Physio 166: 1968-1981.

41. Djerroudi ZO, Belkhodja M, Bissati S \& Hadjadji S (2011). Effect of salt stress on the proline accumulation in young plants of Atriplex halimus L. et Atriplex canescens. Eur J Sci Res 41(2): 249-260.

42. Romheld V \& Kirkby EA (2010). Research on potassium in agriculture: Needs and prospects. Plant Soil 335: 155-180.

43. Egilla JN, Davies FT \& Drew MC (2001). Effect of potassium on drought resistance of Hibiscus Rosa-sinensis cv. Leprechaun: Plant growth, leaf macro and micronutrient content and root longevity. Plant Soil 229: 213-224.

44. Tariq M, Saeed A, Nisar M, Mian IA \& Afzal M (2011). Effect of potassium rates and sources on the growth performance and on chloride accumulation of maize in two different textured soils of Haripur, Hazara division. Sarhad J Agri 27(3): 415-422.

45. Grattan SR \& Grieve CM (1999). Salinity-mineral nutrient relation in horticultural crops. Sci Horti 1999; 78: 127-157.

47. Snapp SS \& Shennan C (1992). Effects of salinity on root growth and death dynamics of tomato, Lycopersicon esculentum Mill. New Phytol 121: 71-79.

48. Batool N, Shahzad A \& Ilyas N (2014). Plants and salt stress. Int J Agri Crop Sci 7 (14): 1439-1446.

49. Meloni DA, Oliva MA, Ruiz HA \& Martinez CA (2001). Contribution of proline and inorganic solutes to osmotic adjustment in cotton under salt stress. $J$ Plant Nutr 24(3): 599-612.

50. Cruz, V \& Cuartero J (1990). Effects of salinity in several development stages of six genotypes of tomato (Lycopersicon spp.). In: Cuartero J, M.L. GomezGuillamon and R. Fernandez-Munoz (Eds). Eucarpia Tomato 90, Proc. XI ${ }^{\text {th }}$.

51. Day SD, Wiseman PE, Dickinson SB \& Harris JR (2010). Tree Root Ecology in the Urban Environment and Implications for a Sustainable Rhizosphere. Arboriculture \& Urban Forestry 36(5): 193-205.

52. Azeem M \& Ahmad R (2011). Foliar application of some essential minerals on tomato (Lycopersicon esculentum) plant grown under two different salinity regimes. Pak J Bot 43(3): 1513-1520.

53. Islam MT, Ara MI, Hossain MA, Sen AK \& Dutta RK (2011). Identification of tomato genotypes for salt tolerance. Int J Sustain Crop Prod 6(1): 17-21

54. Ahmad AA (2013). Effect of salinity and NPK fertilizer on tomato (Lycopersicon esculentum $\mathrm{L}$ ) growth and productivity in Dongola area. $\mathrm{PhD}$ thesis. College of Agri. Studies, Sudan Univ. Sci. Tech., Sudan.

55. Thomas JC, McElwain E \& Bohnert HJ (1992). Convergent induction of osmotic stress-responses: ABA and cytokinin and the effects of $\mathrm{NaCl}$. Plant Physiol 100: 416-423.

56. Najla S, Vercambre G, Pages L, Grasselly D, Gautier H \& Genard M (2008). Effect of salinity on tomato plant architecture. Acta Horti 801: 1183-1190.

57. Molazem D, Qurbanov EM \& Dunyamaliyev SA (2010). Role of proline, $\mathrm{Na}$ and chlorophyll content in salt tolerance of corn (Zea mays) L. American-Eurasian J Agri Envir Sci 9: 319-324.

58. Nawaz K, Talat AI, Hussain K \& Majeed A (2010). Induction of salt tolerance in two cultivars of sorghum (Sorghum bicolor L.) by exogenous application of 
proline at seedling stage. World Appl Sci J 10: 93-99.

59. Yeo AR, Lee KS, Izard P, Boursier PJ \& Flowers TJ (1991). Short and long term effects of salinity on leaf growth in Rice (Oryza sativa L.). J Exp Bot 42: 881-889.

60. Johnson RW, Dixon MA \& Lee DR (1992). Water relations of the tomato fruit during growth. Plant Cell Enviro 15: 947953.

61. Pervez H, Ashraf M \& Makhdum MI (2004). Influence of potassium nutrition on gas exchange characteristics and water relations in cotton (Gossypium hirsutum L.). Photosynthetica 42: 251-255.

62. Egilla JN, Davies FT \& Boutton TW (2005). Drought stress influences leaf water content, photosynthesis, and wateruse efficiency of hibiscus Rosa-sinensis at three potassium concentrations. Photosynthetica 43: 135-140.

63. Tsonev T, Velikova V, Yildiz-Aktas L, Gurel A \& Edreva A (2011). Effect of water deficit and potassium fertilization on photosynthetic activity in cotton plants. Plant Biosystems 145: 841-847.

64. Hajiboland R, Aliasgharzadeh N, Laiegh SF \& Poschenrieder C (2010). Colonization with arbuscular mycorrhizal fungi improves salinity tolerance of tomato (Solanum lycopersicum L.) plants. Plant Soil 331: 313-327.

65. Rahman MJ, Uddin MS, Bagum SA, Mondol ATMAI \& Zaman MM (2006). Effect of mulches on the growth and yield of tomato in the costal area of Bangladesh under rainfed condition. Int $J$ Sustain Crop Prod 1: 06-10.

66. Gong X, Chao L, Zhou M, Hong M, Luo L, Wang L, Ying W, Jingwei C, Songjie G \& Fashui H (2011). Oxidative damages of maize seedlings caused by exposure to a combination of potassium deficiency and salt stress. Plant Soil 340: 443-452.

67. Hartz TK, Miyao G, Mullen RJ, Cahn MD, Valencia J \& Brittan KL (1999). Potassium requirements for maximum yield and fruit quality of processing tomato. J Amer Soc Horti Sci 124: 199204.

68. Khayyat M, Tafazoli E, Eshghi S, Rahemi M \& Rajaee S (2007). Salinity, Supplementary Calcium and Potassium Effects on Fruit Yield and Quality of Strawberry (Fragaria ananassa Duch.). American-Eurasian J Agri \& Envir Sci 2(5): 539-544.

69. Loch J \& Petho F (1992). Effect of potassium sulphate on the yield of vegetable: In: Proc. Potash in Ecosystem, $23^{\text {rd }}$ Colloquium, Potash Institute, October 12-16, Prague. 407-409.

70. Kaviani I, Basirat M \& Malakouti MJ (2004). A comparison between the effects of fertigation and soil application of potassium chloride and soluble SOP on the yield and quality of tomato in Borazjan Region of Boushehr. In: Proc. IPI workshop on potassium and fertigation development in West Asia and North Africa, Rabat Morocco, November, 24-28, 2004. 